\title{
Finska språkbadselevers bruk av passiv
}

\section{Nyqvist, Eeva-Liisa}

2021-05-12

Nyqvist, E-L \& Lindström Tiedemann , T 2021 , ' Finska språkbadselevers bruk av passiv ' , pÿNordand, vol. 16 , nr. 1 , s. 3656 . https://doi.org/10.18261/issn.2535-3381-2021-01-03

http://hdl.handle.net/10138/331917

https://doi.org/10.18261/issn.2535-3381-2021-01-03

unspecified

acceptedVersion

Downloaded from Helda, University of Helsinki institutional repository.

This is an electronic reprint of the original article.

This reprint may differ from the original in pagination and typographic detail.

Please cite the original version. 
Finska språkbadselevers bruk av svensk passiv

Svensk passiv har flera olika former (s-passiv, vara- och bli-passiv). $S$-passivens dominans i svenska är också en tydlig skillnad mellan svenska och de andra nordiska språken. I den här artikeln analyserar vi L2-svenska översättningar av finska meningar för att se hur väl språkbadselever lärt sig passiven och vilken passivkonstruktion de föredrar. Vi jämför språkbadselever i årskurs 6 och 9 för att se om det blir en förbättring och också för att se om det finns en skillnad i vad de verkar ha problem med eller vad gäller vilken passivkonstruktion som de föredrar.

Våra resultat visar att $s$-passiven är den vanligaste i båda årskurserna precis som i L1-svenska och att de perifrastiska passivkonstruktionerna används mer i årkurs 9 men att de då fortfarande är problematiska. Årskurs 9 har högre formell korrekthet i sitt bruk av s-passiven och varapassiven, men eftersom de använder fler komplexa former kan det ibland leda till normavvikelse. $\mathrm{Vi}$ ser att det finns problem främst $i$ relation till formen $i$ passivkonstruktionerna och inte så mycket $\mathrm{i}$ valet av passivkonstruktion, men det kan också vara svårt att bedöma konstruktionsvalet utan ett mer omfattande sammanhang varför vi anser att det vore värt att titta vidare på konstruktionsvalet i framtiden.

Nyckelord: Svenska som andraspråk, svensk grammatik, komplexitet, språkbad, passiv 


\section{Inledning}

Svensk passiv har flera olika former ( $s$-, vara- och bli-passiv). ${ }^{\mathrm{i}}$ I en finsk kontext ser vi att svenskans passiv har en lite annan funktion än den finska passiven som måste tas i beaktan $\mathrm{i}$ undervisningen, dessutom påverkar den satsens struktur lite annorlunda än i finskan. Svenska i Finland lärs in som andraspråk både i traditionell undervisning och i språkbad. Inom bruksbaserade teorier om språkinlärning är input centralt och då passiv är något som introduceras ganska sent i traditionell andraspråksundervisning vill vi här fokusera på hur elever i språkbad hanterar svenskans passivkonstruktioner, eftersom input är betydligt mer omfattande i språkbad.

Svenskt språkbad erbjuds för finskspråkiga barn inom dagvården ${ }^{\mathrm{ii}}$ och grundskolan. Målet är funktionell tvåspråkighet, dvs. förmågan att använda både förstaspråket $(L 1)$ och andraspråket (L2) på ett lämpligt sätt i olika situationer (Genesee, 2004). I dagvården tillägnas språkbadsspråket genom dagliga aktiviteter med pedagoger som talar svenska men som även förstår finska. I skolan får eleverna viss explicit undervisning i L2 (Bergroth \& Björklund, 2013, s. 97), men huvudvikten ligger på implicit inlärning genom såväl svenskämnet som övriga skolämnen. Andelen undervisning på L1, finska, ökar gradvis i grundskolan. I årskurserna 7-9 får eleverna ungefär lika mycket undervisning på finska och på svenska. (Bergroth \& Björklund, 2013, s. 109.)

Språkbadseleverna utvecklar betydligt bättre kunskaper i språkbadsspråket än inlärare i traditionell undervisning (Lyster, 2007, s. 11-12; Bergroth, 2015, s. 108). Internationella och finländska undersökningar har dock visat problem med grammatiken (t.ex. Harley, 1993, 1998; Ó Duibhir, 2009; Sipola, 2008). Studier med ett stort antal språkbadselever har dock varit få i Finland (Bergroth \& Björklund, 2013; se dock Nyqvist, 2018abc, 2020, Nyqvist \& Lundkvist, 2020).

\subsection{Syfte och forskningsfrågor}

Vårt syfte är att analysera hur finskspråkiga språkbadselever i årskurserna 6 (åk6) och 9 (åk9) behärskar svensk passiv. Vi strävar efter att identifiera de mest problematiska konstruktionerna för att kunna bidra till utvecklingen av undervisningen av L2-svenska och förståelsen av vad som gör konstruktionerna svåra. Passiven är ett centralt fenomen i skriftspråket, men är relativt lågfrekvent i inputen (Laanemets, 2012) och konstruktionerna anses vara något som inlärare lär sig ganska sent (jfr t.ex. Inkinen-Järvi \& Jokinen, 2016).

Den grundläggande principen i språkbad är att elevernas L1 är majoritetsspråket i det omgivande samhället, medan språkbadsspråket är ett nationellt minoritetsspråk (Bergroth, 2015). Svenskan är officiellt ett nationalspråk i Finland men talas bara av ca $5 \%$ av befolkningen (Finlands officiella statistik, 2019). I Finland är språkbadseleverna nästan enbart enspråkigt finskspråkiga (Bergroth, 2015), men barn med andra L1 utesluts inte (Utbildningsstyrelsen, 2014). Denna studie fokuserar på enbart finskspråkiga informanter.

Följande frågor är centrala i vår studie:

1. Hur frekvent använder informanterna de passiva konstruktionerna?

2. Vilka är de typiska problemen? Gäller det valet av den idiomatiska konstruktionen eller rent formella aspekter?

3. Hur normenlig är passivkonstruktionens form?

4. Hur skiljer sig produktion i åk6 och åk9 från varandra? 
I avsnitt 2 beskriver vi passiven i svenska och finska och analyserar konstruktionerna ur inlärarsynvinkel, sedan redogör vi för tidigare forskning. I avsnitt 3 presenterar vi materialet och metoden i den aktuella studien. Avsnitt 4 består av en kvantitativ och kvalitativ analys av materialet och avsnitt 5 av en sammanfattande diskussion.

\section{Teori och tidigare forskning}

\subsection{De passiva konstruktionerna i svenskan}

Passiven är en konstruktion som varierar mycket mellan olika språk (Abraham, 2006, s. 5). Svenskan har tre olika huvudkonstruktioner för att bilda passiv (s.k. egentlig passiv): den morfologiska $s$-passiven och perifrastiska (jfr SAG 4, s. 382) vara- och bli-passiverna (se ex. 1-3), och dessa är inte helt synonyma.

\section{Fönstren ska stängas innan man lämnar kontoret.}

2. Pensionären blev rånad vid affären.

3. Fönstren ska vara stängda innan man lämnar kontoret.

Svenskan utmärker sig bland de skandinaviska språken genom $s$-passivens höga andel (se Laanemets, 2012, 2013; Engdahl, 2006; Martola, 2014). Förutom att en inlärare behöver lära sig tre passiva konstruktioner och hur de används tillkommer också komplikationen med att den svenska s-passiven och deponenskonstruktionerna (t.ex. jag andas, vi träffas SAG4, s. 401-402) är formellt identiska. Det här gör det svårare för inläraren eftersom $s$-formen i input måste sorteras i passiver och icke-passiver.

\subsection{En typologisk jämförelse mellan passiver i finska och svenska}

Passivens pragmatiska funktioner i världens språk brukar anses vara antingen topikalisering eller att göra något opersonligt (Siewierska, 1984, s. 2 och kap. 6). Ett språk med strikt ordföljd såsom svenska behöver konstruktioner såsom passiven för att visa på informationsstrukturen i satsen. I och med att ordföljden ofta är det enda som anger vad som är subjekt respektive objekt i svenska satser utgör passiven en viktig möjlighet att kunna variera tema och rema genom att lyfta patienten/föremålet till subjekt och en tidigare position i satsen. (SAG 4, s. 360). I språk med en friare ordföljd (såsom finska) är det möjligt att tematisera en konstituent med hjälp av ordföljden, varför passiven i finskan enbart anger okänd eller dold agens (Karlsson, 2009, s. 103; jfr Abraham, 2006, s. 1-2; Siewierska, 1984). Man skulle kunna ifrågasätta om den finska och den svenska passiven har något gemensamt (jfr Siewierska, 1984, s. 1), en mycket viktig fråga ur inlärarsynvinkel.

Relationen mellan passiven i finskan och svenskan kompliceras ytterligare av att även mankonstruktionen ofta kan översättas till en passivkonstruktion i finskan (Löflund, 1998). Dessutom kan man inte tala om en passivtransformation i finskan såsom i de indoeuropeiska språken (Hakulinen \& Karlsson, 1979, s. 174, 255). När en finsk sats passiveras, sker det inte nödvändigtvis en strukturell förändring, utan objektet i den aktiva satsen kan behålla samma kasusform även i den passiva satsen (se ex. 4-5): 


\section{AKTIV}

$\begin{array}{lll}\text { Kaikki } & \text { ihailivat } & \text { häntä. } \\ \text { Alla.NOM beundra.PRET.3PL } & \text { han.SG.PART } \\ \text { Alla beundrade honom. } & \end{array}$

\section{PASSIV}

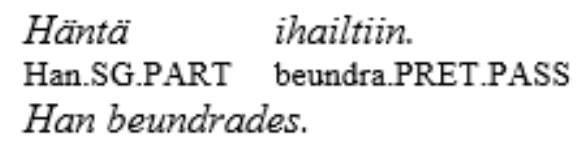

Föremålet kan topikaliseras i den passiva satsen såsom i svenska (5), men det är inte nödvändigt att passivera för att kunna topikalisera föremålet, och det påverkar inte argumentets kasus. Det är också acceptabelt att kombinera aktiv form med topikaliserat föremål (6), eller att inte topikalisera föremålet i den passiva konstruktionen (7), utan låta det stå efter predikatet och i samma kasusform som i den aktiva satsen (8).
6. AKTIV

$\begin{array}{lll}\text { Näyttelyä } & h e & \text { katselivat. } \\ \text { Utstallning-SG.PART } & \text { de.NOM } & \text { se.på-PRET.3PL } \\ \text { Det var en utställning de såg på. } & \end{array}$
7. PASSIV
Katseltiin näyttelyä.
se på-PRET.PASS utställning-SG.PART
Utställningen sågs (av oss).
8. AKTIV

$\begin{array}{lll}\mathrm{He} & \text { katselivat } & \text { näyttelyä. } \\ \text { de.NOM } & \text { se.på-PRET.3PL } & \text { utställning-SG.PART } \\ \text { De såg på } & \text { en } & \text { utställning. }\end{array}$

\subsection{Bruksbaserat perspektiv på inlärningen av svensk passiv}

Mycket forskning tyder på att inputfrekvensen påverkar hur vi lär oss språk (se t.ex. N. Ellis, (2011 [2013]). Vilken effekten blir på förståelse (och inlärning) tolkas inom competition model (CM; Bates \& MacWhinney, 1989; Li \& MacWhinney, 2013) som ett resultat av en kombination av förekomsten i inputen och tillförlitligheten. Vi får morfologiska, syntaktiska och semantiska ledtrådar (eng. cues) som hjälper oss koppla ihop form och betydelse i språket. Baserat på hur ofta de förekommer och hur ofta de tolkas rätt har ledtrådar olika validitet (cue validity). Det kan finnas olika ledtrådar i en mening och dessa kan peka åt olika håll dvs. tävla med varandra, eller åt samma håll. Om flera ledtrådar pekar åt samma håll är det lättare att förstå och även att lära sig. Men ordföljd och morfologi kan också peka åt olika håll vad gäller hur syntaktisk funktion ska tolkas och då är det frågan vilken av de två ledtrådarna som har högre validitet och som vinner i tolkningen. Här skiljer sig validiteten i olika språk. Modellen menar att såväl inputfrekvenserna som inlärares egenskaper, t.ex. deras L1, spelar en roll för hur väl något kommer att förstås (Li \& MacWhinney, 2013, s. 3). Därför är det viktigt att se närmare på hur inlärarnas input ser ut.

Tyvärr har vi inte tillgång till vad inlärare läser och hör, men som en approximation till detta vad gäller egentlig passiv kan vi jämföra med Laanemets analyser av såväl skriftspråk som talspråk. Hennes analyser av tidningstexter visar att s-passiv är vanligast (91\%), medan andelen vara- och bli-passiv är bara $7 \%$ resp. $1 \%$. S-passiven har också visat sig vara den dominanta 
typen av passiv i uppsatserna av svenskspråkiga gymnasister, i synnerhet hos finlandssvenskar (Neuvonen, 1997, s. 186-187).

Då L2-inlärning i språkbad börjar tidigt och utan tidigare kunskaper i språkbadsspråket, är det möjligt att dra paralleller mellan den och L1-inlärningen. Det finns också åtminstone en CMstudie (Liu m.fl., 1992) som visat att de som hade börjat lära sig L2 tidigt inte använde L1ledtrådars värden när de tolkade L2. Dessa inlärare kunde istället använda L2-ledtrådars värde i tolkningen av L1 eller tydligt hålla språkens värden separata (Liu m.fl., 1992). Enligt bruksbaserad grammatik memorerar inlärare först konkreta yttranden. Med tiden upptäcker de mönster i dessa (Bybee, 2008), och det har föreslagits att man borde uppmuntra mönsterigenkänning mer inom L2-undervisning (Håkansson m.fl, 2019; Prentice m.fl., 2016; Lyngfelt \& Prentice, 2020). Frekvensen är en central faktor i processen, men även högfrekventa grammatiska morfem är svåra att lära sig om de har låg saliens, dvs. om de är svåra att lägga märke till i inputen (N. Ellis, 2016, s. 342). Detta stämmer väl överens med CM:s idé om att ledtrådars värde inte bara påverkas av frekvensen utan också av hur ofta de tolkas rätt. I princip har detta att göra med om konstruktionerna är polysema, men saliensen kan också spela in.

Många L2-strukturer kan inte läras in helt utan explicit undervisning (Skehan, 1998). Enligt DeKeyser (2005, s. 3) kan svårigheterna bero på målspråksstrukturens betydelse, form eller förhållandet mellan formen och betydelsen. På liknande vis ser N. Ellis (2011 [2013], s. 198, 200) frekvensen $i$ inputen, formen, funktionen och samverkan mellan alla dessa tre faktorer som viktiga för inlärningen. CM menar likaså att en ledtråds validitet är en kombination av dess frekvens och hur ofta något tolkas rätt. Ledtrådens styrka i L2 baseras dock först på tillgängligheten, frekvensen, medan hur ofta/lätt den tolkas rätt senare blir det viktigaste (Li \& MacWhinney, 2013, s. 1-2).

Enligt DeKeyser (2005, s. 5) är betydelsen svårtillgänglig om den är abstrakt eller om den inte förekommer som kategori i inlärarens tidigare språk. Detta gör det då sannolikt också att tolkningen från input blir problematisk och avviker från målspråkets normer. Passiven är en heterogen lingvistisk kategori och skiljer sig åt mellan finska och svenska (se ovan) såväl i funktion som form samt påverkan på argumentens (morfo)syntax. Dessutom har finskan endast en passivform medan svenskan har tre och de olika passivformerna är inte sinsemellan helt utbytbara, utan det handlar ofta om subtila nyanser (SAG4, s. 397-401) som ter sig diffusa för inlärare, dvs. svensk passiv är svårtillgänglig för finskspråkiga i DeKeysers mening.

Perifrastisk passiv är formellt komplex: man väljer mellan två hjälpverb (SAG4, s. 382) och bildar perfekt particip av huvudverbet. Att bilda particip är en svår uppgift i sig, eftersom verbets konjugation spelar en avgörande roll (t.ex. Holmes \& Hinchcliffe, 1994, s. 268) och participen kongruerar dessutom med subjektet i genus och numerus (SAG2, s. 594-599). Ytterligare har perfekt particip i neutrum singularis ofta samma form som supinum (SAG2, s. 597), som även betydelsemässigt står participen nära. Därför är det möjligt att inlärare föredrar s-passiven (jfr R. Ellis, 2008, s. 357-358 översikt som visar att komplexa strukturer undviks enligt flera studier). Om vi vill studera undvikande måste vi dock tänka på att inläraren bara kan undvika en konstruktion vars existens hen är medveten om. Dessutom behövs det bevis på att L1-talare skulle använda den formen som eventuellt undviks i den aktuella kontexten om vi ska argumentera för att något har undvikits (Seliger, 1989, s. 22). Att få bevis på om våra informanter är medvetna om alla passiva konstruktionerna skulle dels förutsätta analys på individnivå, dels mer noggrann information om inlärarnas förståelse och medvetenhet kring passiv i svenska. Tyvärr är detta inte möjligt på basis av det material vi har att tillgå. Vi kan inte heller anta att L1-skribenter skulle använda t.ex. bli-passiv i en kontext där $s$-passiven är 
möjlig. Det finns en variation i valet av passivkonstruktion bland L1-skribenter, men $s$-passiven dominerar kraftigt.

$S$-passivens form är mindre komplex än den perifrastiska passivens. Den kan dock bereda svårigheter i presens där $r$ som inte ingår i verbets stam avlägsnas ( $t$ ä̈ttar $\rightarrow$ tvättas), eftersom en L2-inlärare inte nödvändigtvis vet i vilka verb $r$ :et ingår i stammen (t.ex. kör $\rightarrow$ körs). $S$ ändelsen har dessutom låg saliens vilket torde komplicera inlärningen.

Förhållandet mellan formen och betydelsen är i de svenska passiva konstruktionerna ogenomskinligt (jfr DeKeyser, 2005, s. 7-10): olika former (framför allt s- och bli-passiv) står för ungefär samma betydelse. Dessutom kan en form ha flera betydelser - alla verb på $-s$ är inte passiva.

Vad gäller ledtrådar är $s$-passiven alltså mer tillgänglig än de andra passivkonstruktionerna i svenska eftersom den är mycket mer frekvent. Men $s$-formerna kan tolkas fel eftersom $s$ ändelsen inte alltid är passiv (att andas). Enligt CM är ledtrådens validitet en kombination av dessa två. Om vi sedan ser på hur detta samspelar med semantiska roller och deras (morfo)syntaktiska uttryck skiljer det sig mycket åt mellan finska och svenska vilket kan få en klar effekt vid språkinlärningen. I svenskan är ordföljden en stark indikator för nominalfrasers funktion som subjekt och objekt, och subjektet i aktiv sats är ofta associerat med agens eller upplevare. I passiva satser har dock subjektet ofta rollen föremål i svenskan. I finskan är ordföljden ingen stark indikator för argumentens syntaktiska funktion och den semantiska rollen representeras främst av kasusformer som även associeras med syntaktiska funktioner. Dessa kasus påverkas inte alltid av den passiva konstruktionen, således kan föremålet formellt ha samma kasus i den passiva konstruktionen (se ex. 4-5 ovan). Detta kan orsaka problem vid språkinlärning då det innebär att passivkonstruktionen i svenska får en viktig roll för tolkningen av argumentens semantiska roller, och således påverkar tolkningen av meningen som helhet mer än i finskan.

\subsection{Tidigare forskning om passiv $i$ L2-svenska}

Passiven har inte undersökts mycket i inlärarsvenskan. Horbowicz m.fl. (2019, s. 10, 21) har dock kartlagt bruket av vissa verb (t.ex. anse, kalla, tänka) i masteruppsatser på danska, norska och svenska av både L1 - och L2-skribenter (L1 polska) av dessa språk. Analysen av det svenska materialet visar att passiv förekommer mer i L1-svenska än i L2-svenska. $S$-passiven dominerar i alla tre språken för både L1- och L2-skribenter, men allra mest i svenska (Horbowicz m.fl., 2019, s. 13).

Normavvikelser för svensk passiv har studerats i två avhandlingar pro gradu. ${ }^{\text {iii }}$ Kantolas (2001) informanter använde vanligen passiv i korrekta kontexter i det finska studentexamensprovet $\mathrm{i}$ L2-svenska. Av de passiva satserna var $74 \% s$-passiv, och passiven var vanligare hos bättre skribenter, med undantag av vara-passiven som var vanligast hos de svagaste (Kantola, 2001, s. 90). Normavvikelserna gällde såväl användningen av passiven som böjningen. Järvinen [Nyqvist] $(2004$, s. 97-98, 101) fann att normavvikelser i uppsatser hos finska gymnasister i åk2 och abiturienter ${ }^{\text {iv }}$ grovt kunde indelas i konstruktioner som använts i en oidiomatisk (se avsnitt 3 för definition) kontext (t.ex. vara-passiv i stället för $s$-passiv) och i icke-normenliga former (95\% av alla normavvikelser). Normavvikelserna var kvalitativt likadana i uppsatserna och i ett grammatiktest ${ }^{\mathrm{v}}$, men deras andel var högre i testet (52\% resp. $44 \%$ ). Abiturienterna klarade de flesta testmeningar bättre än åk2. 
På formnivå förekom det förväxling av infinitiv och presens i s-passiv (*Om människan jämföras... Kantola, 2001, s. 75-76) som troligen beror på att inlärarna inte vet vilken verbets stam är. Järvinen [Nyqvist] (2004) fann att i s-passiven var bortfall av passivmarkeringen (Det * säger att...) vanligaste normavvikelsen. Vad gäller den perifrastiska passiven förekom ickenormenlig konjugation (*skötat), kongruensproblem (djuret är *älskad) och överanvändning av supinum (bli*tagit; Kantola, 2001, s. 78-80; Järvinen [Nyqvist], 2004). Järvinen [Nyqvist] (2004) fann dessutom att icke-normenliga participformer var vanligare i testet än i uppsatserna, troligen pga. att testet innehöll flera starka verb. I båda avhandlingarna förekom också blandformer (Man kan *sägas...; Finland är *käns...) (Kantola, 2001, s. 71; Järvinen [Nyqvist], 2004, s. 96).

Tidigare studier har således visat viss återhållsamhet i passivanvändningen i L2-svenska i jämförelse med L1-svenska (Horbowicz et al, 2019) och att normavvikelser fortfarande förekommer i L2-svenska i slutet av gymnasiet i Finland (Kantola, 2001; Järvinen [Nyqvist], 2004). I den här studien tittar vi på yngre inlärare än i de tidigare studierna och från språkbad, medan gymnasisterna i tidigare studier sannolikt gått främst i traditionell undervisning.

\section{Material och metod}

Syftet med denna artikel är att analysera hur finskspråkiga språkbadselever i åk6 (12-åringar, $\mathrm{n}=124$ ) och i åk9 (15-åringar, n=147) behärskar svensk passiv. Materialet samlades in under våren 2014 i sju städer där språkbad erbjuds. Det består av ett översättningstest från finska till svenska med sammanlagt 13 meningar varav 11 är relevanta för oss här ${ }^{\mathrm{vi}}$ (se Bilaga 1). Meningarna representerar olika regler ur en svensk grammatik för finskspråkiga. Testet är detsamma som i Järvinen [Nyqvist] (2004). Vi analyserar dock det aktuella språkbadsmaterialet på ett annat sätt än Järvinen [Nyqvist] (2004) utifrån andra möjliga svar efter en noggrann genomgång av Therese Lindström Tiedemann som är L1-talare av svenska i samråd med andra svenskspråkiga kollegor. Därför är resultaten i Järvinen [Nyqvist] (2004) inte jämförbara kvantitativt. Översättning har traditionellt inte ingått i språkbad (Laurén, 2006, s. 53) och ett översättningstest ökar sannolikheten för interlingvala normavvikelser (LoCoco, 1976, s. 77). Trots detta är ett översättningstest ett fungerande sätt att elicitera passiva konstruktioner som är sällsynta i spontana material (jfr Järvinen [Nyqvist], 2004, s. 56). Testet skrevs på lektionstid utifrån instruktionen att de skulle översätta satserna till svenska och utan närmare information om att en viss konstruktion (passiv) skulle användas. Informanterna fick hjälp med ordförrådet, men inte med grammatiken.

Totalt består materialet av 1337 meningar i åk6 och 1592 i åk9. Av dessa förekommer egentlig passiv i 509 resp. 1003 meningar (299 resp. 511 belägg på s-passiv, 47 resp. 112 belägg på blipassiv och 163 resp. 380 belägg på vara-passiv). Som figur 1 visar var de aktiva konstruktionerna (speciellt man-konstruktionen) synnerligen vanliga i åk6. Dessutom förekommer det blandformer ( 25 resp. 75 belägg) och oanalyserbara fall (50 resp. 7 belägg). Av dessa utelämnas man-konstruktionen och de oanalyserbara fallen från analysen.

Figur 1. Andelarna egentlig passiv och övriga konstruktioner i åk6 och åk9. 


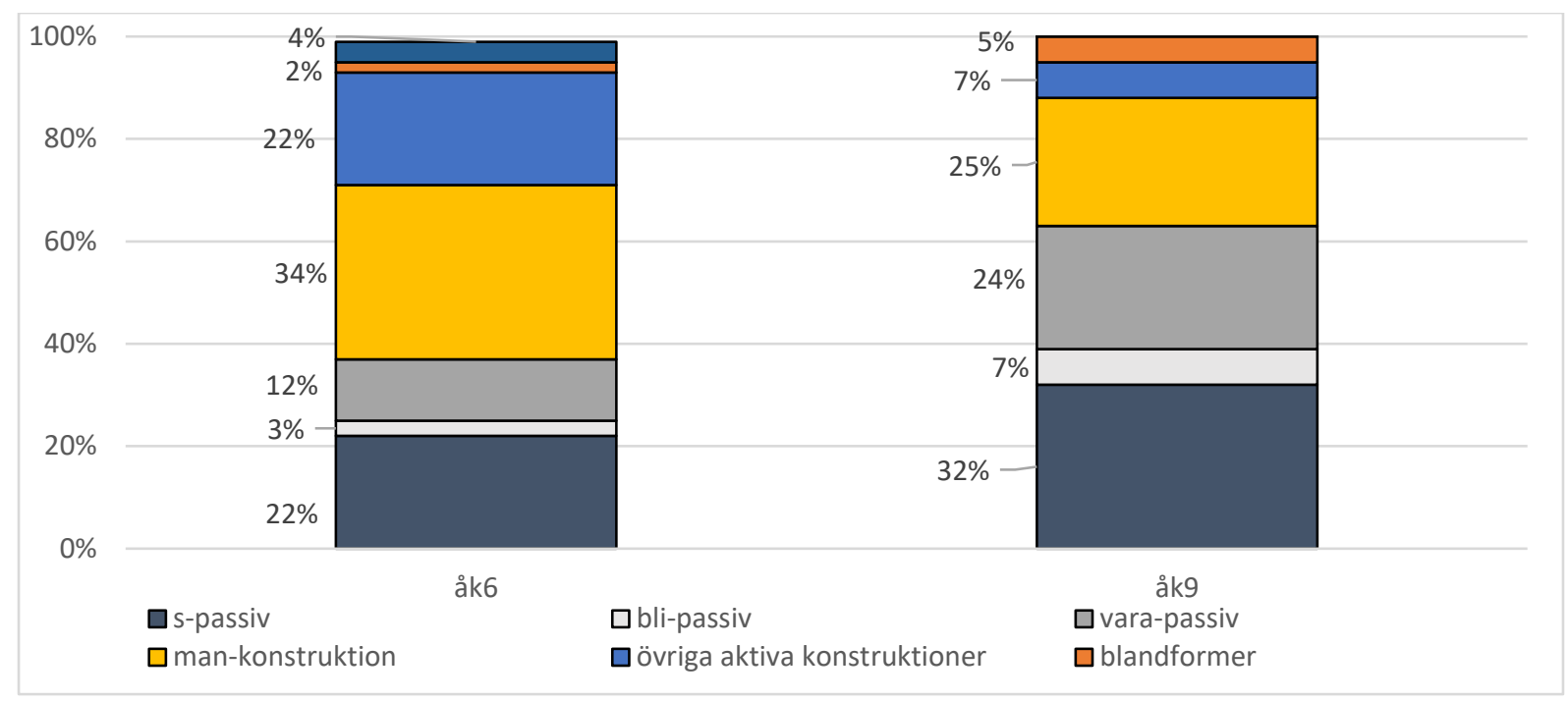

Egentlig passiv är alltså klart vanligare i åk9, men Figur 2 visar att egentlig passiv är ovanlig i mening 12b (t.ex. 12a: Det berättas, 12b: att björnar har setts $i$ Åbotrakten.) även i åk9, även om L1-talare skulle acceptera alla passivtyperna i det fallet och $s$-passiv brukar vara vanligast i L1-svenska men då det här är en bisats så beror det också på vad som kommer i huvudsatsen. Sannolikt är det den komplexa satsstrukturen (12a-b) som delvis orsakar avhållsamheten från egentlig passiv i 12b och även L1-talare skulle här gärna välja man-konstruktion (12b: att man sett björnar i Åbotrakten.).

Figur 2. Andelarna egentlig passiv och övriga konstruktioner i de enskilda meningarna i åk6 och åk9

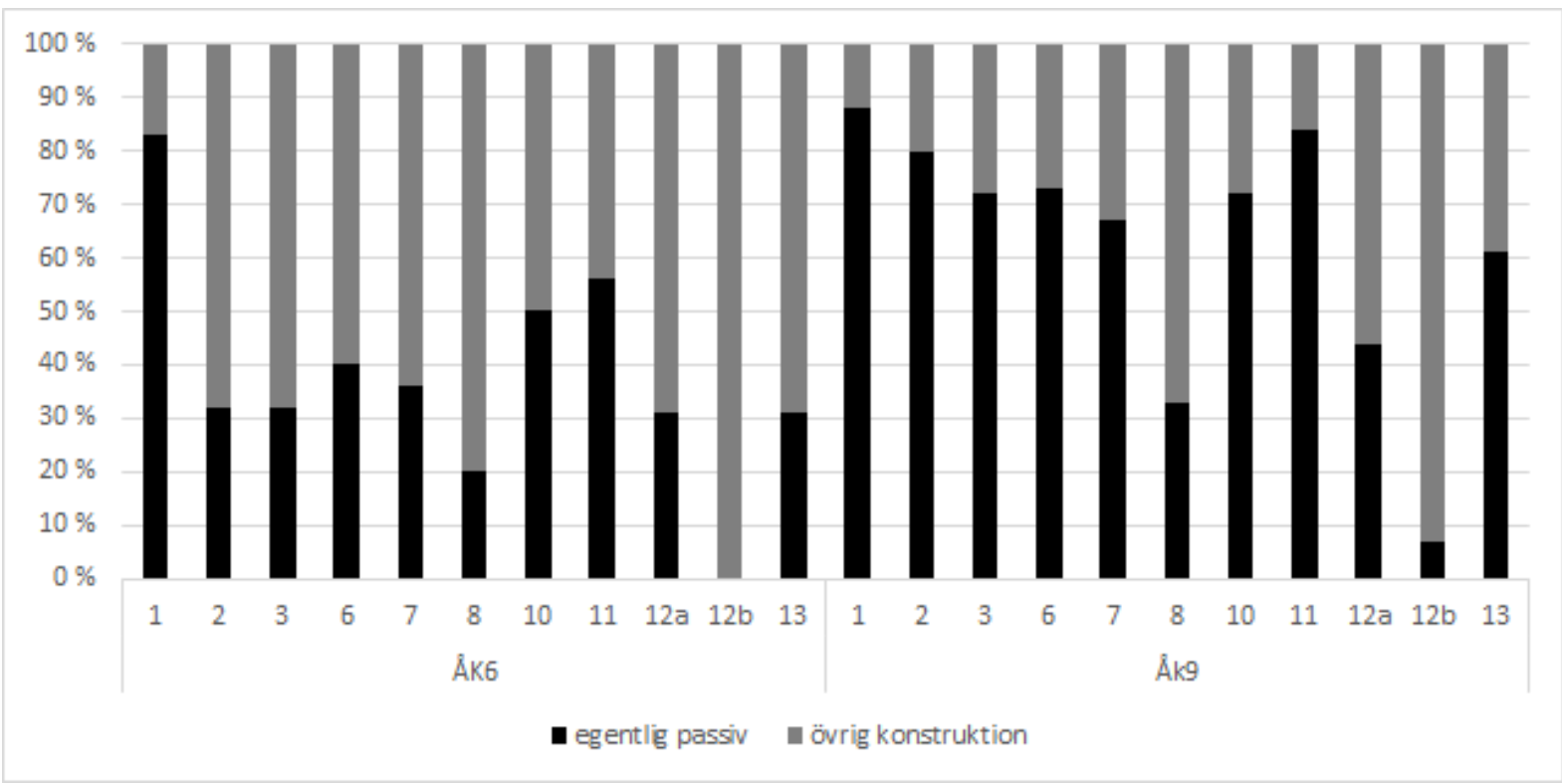

Analysen sker på gruppnivå. Eftersom de flesta finska meningarna i testet kan översättas med flera olika konstruktioner bygger analysen på de s.k. inlärarkontexterna (i fortsättningen $I L$ kontexterna, jfr Juurakko, 1996, s. 72), dvs. på det som informanterna faktiskt har producerat. ${ }^{\text {vii }}$ Exempelvis Hon *var sägt upp har klassificerats som vara-passiv. En nackdel med ILkontextanalys är att alla informanternas konstruktioner inte passar in i de etablerade grammatiska kategorierna. Blandformer såsom Man berättas att... bär drag av både man- 
konstruktionen och s-passiven, och det är omöjligt att avgöra vad informanten ville använda. Därför har blandformerna klassificerats som en egen kategori (jfr Kantola, 2001; Järvinen [Nyqvist], 2004) som kortfattat kommenteras i avsnitt 4.3.

Beläggen har ytterligare klassificerats utifrån idiomaticiteten eftersom tidigare forskning visat en viss underanvändning av passiv i L2-svenska (Horbowicz et al, 2019) och viss överanvändning av vara-passiven (Kantola, 2001; Järvinen [Nyqvist], 2004). Vi ser idiomaticitet som en skala där vi menar att ett idiomatiskt uttryckssätt är ett som en L1-talare mer sannolikt skulle tänkas använda, medan ett oidiomatisk uttryckssätt kan vara grammatiskt korrekt och lexis kan tyckas passa men ändå brukar L1-talare inte uttrycka sig så (jfr Warren, 2005, jfr nativelike selection i Pawley \& Syder, 1983). Det är svårt att med fullkomlig säkerhet bedöma idiomaticiteten i belägg som består av meningar utan kontext. Therese Lindström Tiedemann som L1-talare har gjort en bedömning av vilka de mest idiomatiska konstruktionerna skulle vara och även konsulterat andra L1-talare, men i vissa kontexter kunde även andra översättningar bli möjliga och i fall såsom mening 3 kan icke-passiva lösningar troligen ses som mer sannolika (t.ex. Man/många beundrade hen på 80-talet.). Eftersom kontexten kan ha ett starkt inflytande och dessa meningar var utan kontext har vi också sett mer osannolika val som idiomatiska i vissa fall, om vi kunnat tänka oss att det kan finnas en kontext där de kunde användas (dessa markeras med ? i Bilaga 1).

Genom vår analys vill vi identifiera såväl de konstruktioner som inlärarna klarar väl (i jämförelse med målspråkets standardnorm) som de konstruktioner som är problematiska ur inlärarperspektiv. Vi strävar inte (i första hand) efter att förklara normavvikelsernas ursprung eller att utveckla metoder för att förebygga dem, vilket är centralt i felanalys (R. Ellis \& Barkhuizen, 2005), utan vi vill endast lyfta fram vad som bereder en större utmaning för inlärare i relation till målspråkets standard och sannolika frekvenser i input. Dessutom studerar vi varför inlärarna klarar andra saker väl. Beläggen har klassificerats utifrån om de är fullständigt normenliga eller om de uppvisar problem som t.ex. bortfall av passivmarkeringen eller i participformen. Vi har dock betraktat enbart normavvikelser som gäller passiv diates: ett ickenormenligt tempus har räknats som korrekt. Eftersom passiven är en egenskap hos satser (dvs. inte enbart verbfraser; SAG 4, s. 360) tar vi dock hänsyn även till subjektets form.

Olika konstruktionstypers andelar i översättningarna har beräknats genom att dividera antalet informanter som använt en viss konstruktion med antalet informanter som skrivit uppgiften: t.ex. eftersom 61 av de 124 sjätteklassarna har använt $s$-passiv i mening 1 så är konstruktionens frekvens $49 \%(61 / 124=0,49)$. Andelarna normenliga belägg har däremot beräknats genom att dividera antalet korrekta IL-kontexter med det totala antalet IL-kontexter för konstruktionen: då 52 av de 61 beläggen på s-passiv i mening 1 är normenliga i åk6 är korrekthetsprocenten 85 $\%(52 / 61=0,85)$. Statistikprogrammet SPSS har använts för att beräkna statistisk signifikans. Vi använder Pearson's $\chi^{2}$ ( $p<0,05$ som gränsvärde) eftersom det inte kräver ett normalfördelat material.

\section{Resultat och analys}

Vi har studerat vilka passivtyper som väljs i de två årskurserna samt hur pass normenligt de används. Som Figur 3 visar används $s$-passiven mest normenligt i båda årskurserna, men vi ser också att korrektheten ökar fler procentenheter för de två perifrastiska passiverna från åk6 till åk9.

Figur 3. Korrekthetsprocenten för de olika konstruktionstyperna i testet 


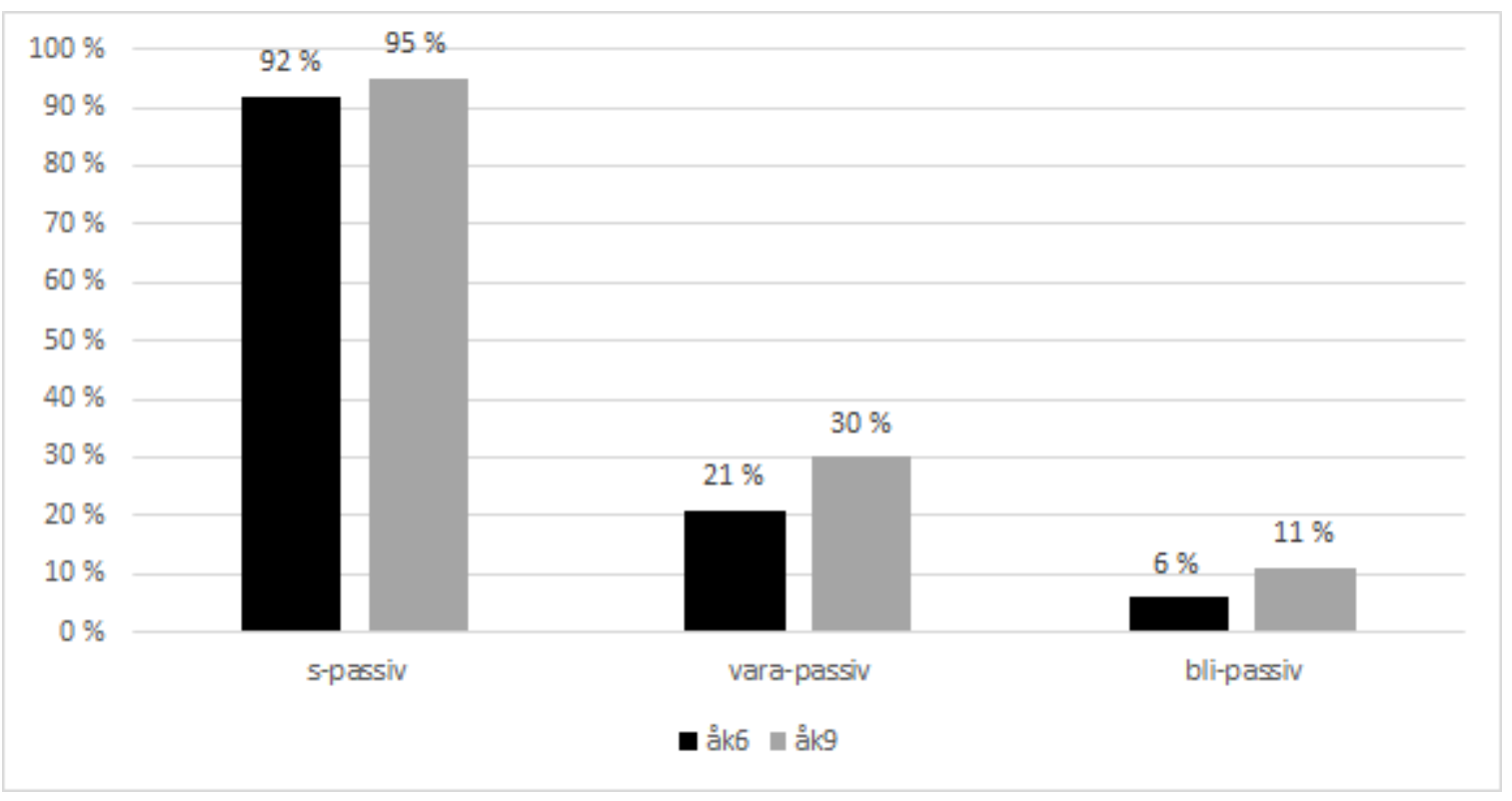

$S$-passiven behärskas i båda årskurserna signifikant bättre än både bli- och vara-passiven ( $\mathrm{p}<0,001 \mathrm{i}$ båda). Detta är föga överraskande då $s$-passiven är formellt sett den minst komplexa typen av de egentliga passivkonstruktionerna och den mest frekventa typen av passiv i modern svenska (Laanemets, 2012, s. 92). S-passiven kan således förväntas vara frekventare än perifrastisk passiv i input. Samtidigt kan det konstateras att detta stämmer bra med bruksbaserade teoriers syn på frekvensens centrala roll för språkinlärning. Även enligt CM är frekvensen viktig, men $s$-formens tvetydighet kunde leda till vissa problem men det är inget vi direkt märker här.

Av de två perifrastiska passivkonstruktionerna behärskas vara-passiven bättre än bli-passiven ( $\mathrm{p}=0,022$ i åk6; $\mathrm{p}<0,001$ i åk9). $S$-passiven och vara-passiven behärskas dessutom i åk9 på en signifikant högre nivå ( $\mathrm{p}=0,044$ resp. $\mathrm{p}=0,022)$ än i åk6 vilket tyder på att en utveckling skett. Nedan redogör vi för frekvenser och korrekthet för de olika passivkonstruktionerna i enskilda meningar.

\subsection{S-passiv}

Frekvensen för $s$-passiven är i flera meningar hög (se figur 4), men det betyder inte att den överanvänds.

Figur 4: Frekvenserna och korrekthetsprocenten för s-passiv 


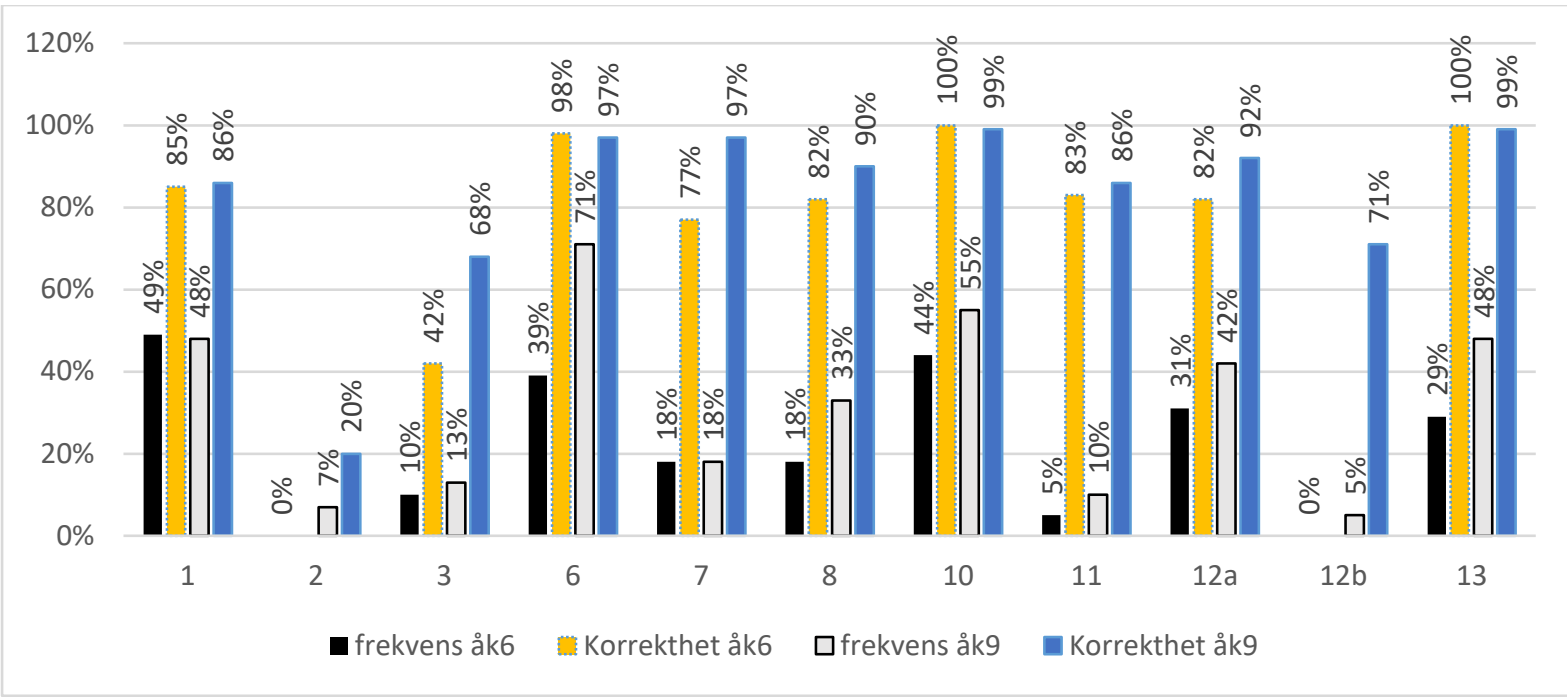

Korrekthetsprocenten för $s$-passiven är $\geq 75 \%$ i de flesta meningar i båda årskurserna (se figur 4). Skillnaderna mellan årskurserna är små med undantag av i mening 7 (Han sades upp) som åk9 behärskar signifikant bättre $(\mathrm{p}=0,049)$. Detta kan bero på att det här är en form som de sannolikt inte hört och läst så ofta men de har valt $s$-passiv för att den är vanligast eller upplevs enklast. Det kan också bero på att preteritumformen av säga i uttalet oftast är sas och inte sades, så tal och skrift stämmer inte överens. Det är intressant att det här är en mening där bli-passiven skulle vara idiomatisk i L1-svenska, vilket stämmer bra med att bli-passiven och $s$-passivens frekvens är ganska lika för inlärarna här (jfr figur 5).

Gemensamt för meningarna med de högsta korrekthetsprocenten (meningarna 6, 10 och $13 \mathrm{i}$ både åk6 och åk9 samt meningarna 2 och $7 \mathrm{i}$ åk9) är att det passivbildande $s$ :et har fogats till preteritum (sades, höjdes) eller till en infinitiv som föregås av ett modalt hjälpverb (ska tvättas, kan byggas). Som vi uppmärksammat ovan så gör detta att $s$-passiven då är enkel att bilda. I meningarna 1 och 8 , där $r$ :et i presens har behövt avlägsnas (stänger $\rightarrow$ stängs; säger $\rightarrow$ sägs) förekommer det däremot normavvikelser i båda årskurserna: Se till att fönstren *stängas; Det *sägst. Mening 1 där predikatsverbet står i presens har båda årskurserna haft signifikant fler problem med än meningarna 6,10 och 13 ( $\mathrm{p}=0,023, \mathrm{p}=0,003$ och $\mathrm{p}=0,016$ i åk6; $\mathrm{p}=0,006$, $\mathrm{p}=0,022$ och $\mathrm{p}=0,005$ i åk9). Detsamma har noterats även i traditionell undervisning (Järvinen [Nyqvist], 2004, s. 84-85, 94). Normavvikelserna i mening 8 är däremot mycket få vilket troligen kan förklaras med att det sägs tillägnats som helsekvens.

Den vanligaste normavvikelsen i $s$-passiv handlar dock om överanvändning av objektsformen när den passiva satsens subjekt är ett pronomen (ex. 9, *Henne beundrades på 80-talet). Detta beror sannolikt på finsk påverkan: i finskan ändras inte kasusformen för den aktiva satsens objekt synbart i den passiva satsen. Den aktiva satsens objekt står visserligen ofta initialt i passiva satser i finskan, men det står fortfarande i oblikt kasus, såsom partitiv (t.ex. häntä, 'honom/henne', jfr subjektsformen hän 'han/hon'), dvs. informanterna har översatt ordagrant från finska till svenska. I alla de fall där denna typ av normavvikelse förekommer i vårt material hade pronomenet i finskan samma form i den passiva satsen som det skulle ha haft i den aktiva. Fenomenet är vanligare i åk6 men det förekommer även hos gymnasiestuderande (Järvinen [Nyqvist], 2004 s. 85, 87).

\section{Häntä Hon-PART ihailtiin beundra-PRET.PASS Hon beundrades på 80-talet.}

80-luvulla (mening 3 ) 80-talet.AD 
Bortfall av formellt subjekt (*Sägs, att hunden är...) har åtta belägg i båda årskurserna (meningarna 8 och 12a) och förekommer även i Järvinen [Nyqvist] (2004). Även denna normavvikelse torde härstamma från finskan där de passiva satserna saknar explicit subjekt:

\section{Sanotaan, että koira on ihmisen paras ystävä. (mening 8) säga-PRS.PASS att hunden är människans bästa vän \\ Det sägs att hunden är människans bästa vän.}

Informanterna i både åk6 och åk9 behärskar s-passiven på en hög nivå, ändå sker det en signifikant förbättring mellan årskurserna. Problemen gäller oftast subjektet och har sina rötter i informanternas L1. Själva verbformen vållar problem enbart i presens som vi också hade förutspått pga. komplikationen med att hitta verbets stam. Normavvikelserna blir mindre vanliga i åk9 utom i några enstaka meningar där korrekthetsnivån redan i åk6 är mycket hög.

\subsection{Perifrastisk passiv}

Figurerna 5-6 sammanfattar frekvenserna och korrekthetsprocenten för bli- resp. vara-passiven i de enskilda meningarna. Vi behandlar först konstruktionsvalen och sedan particip eftersom det är ett gemensamt element för bli- och vara-passiven.

Figur 5: Frekvenserna och korrekthetsprocenten för bli-passiv

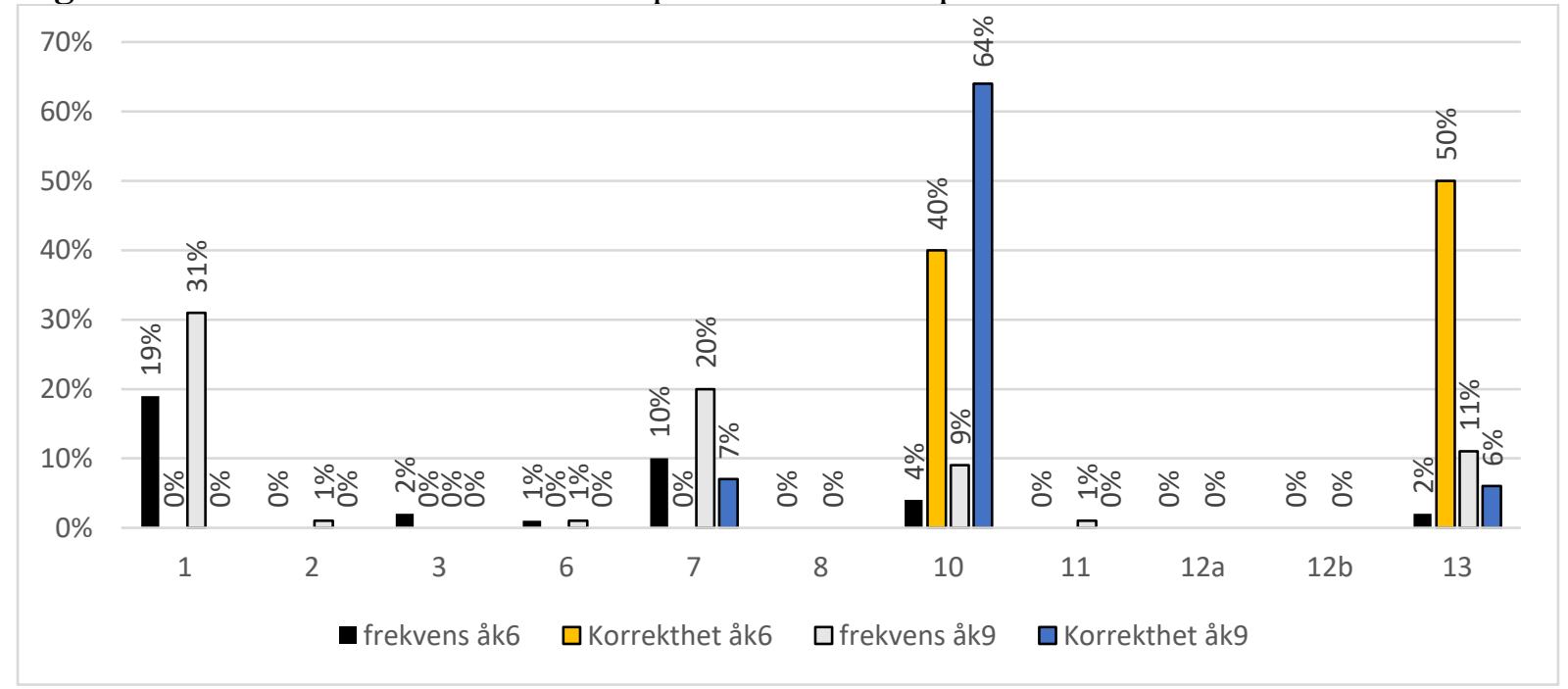

Bli-passiven är sällsynt både $\mathrm{i}$ materialet och i dagens svenska (Laanemets, 2012). I vårt material är den så lågfrekvent (47 belägg i åk6, 112 belägg i åk9) att det är möjligt att den undvikits, men det är dock oklart om alla i åk6 ens känner till bli-passiven. Frekvensen är i båda årskurserna högst i mening 1 (ex. 11). Men den är inte naturlig att använda där, eftersom den finska meningen betonar själva handlingen vilket gör att $s$-passiv skulle varit ett mer lämpligt val. Perifrastiska översättningar av meningen tolkas som att man ska övervaka en process (... att fönstren blir stängda!), eller att man ska kontrollera att de redan är stängda (... att fönstren är stängda!).

$\begin{array}{llll}\text { 11. Huolehdi, } & \text { että } & \text { ikkunat } & \text { suljetaan! (mening 1) } \\ \text { se.till-SG.IMP } & \text { att } & \text { fönster.PL.NOM } & \text { stänga.PRS.PASS } \\ \text { Se till att fönstren stängs! } & & \end{array}$


Bli-passiven förknippas vanligen med resultat och förändringar i tillstånd (SAG4, s. 391-392; Engdahl, 2006), och därför är det naturligt att den är relativt vanlig (10\% resp. $20 \%)$ i mening 7 (Hen blev uppsagd) och i åk9 i mening 13 (11\%, Huset kan bli byggt nästa år). Korrekthetsprocenten är dock låg pga. problemen med participformen. Den klart högsta korrekthetsprocenten (64\%) i materialet förekommer i åk9 i mening 10 (Priserna blev höjda) där majoriteten har bildat participet korrekt. Här är participet ganska lätt att bilda eftersom verbet höja böjs regelbundet. Dessutom blandas pluralformen inte lika lätt ihop med supinum.

Vara-passiv är mer frekvent än bli-passiven, men frekvensen varierar kraftigt i de olika meningarna i båda årskurserna (se figur 6). Att konstruktionen används i fler kontexter i åk9 kan bero på transfer från engelskan eftersom konstruktionen påminner om engelskans passiv och niondeklassare har hunnit lära sig mer engelska än sjätteklassare. I modern svenska är varapassiven sällsyntare än $s$-passiven men den är något vanligare än bli-passiven (Laanemets, 2012). I vårt material är vara-passiven i synnerhet i åk9 så frekvent ( $24 \%$ av alla formuleringar) att den knappast undviks medvetet.

Figur 6: Frekvenserna och korrekthetsprocenten för vara-passiv

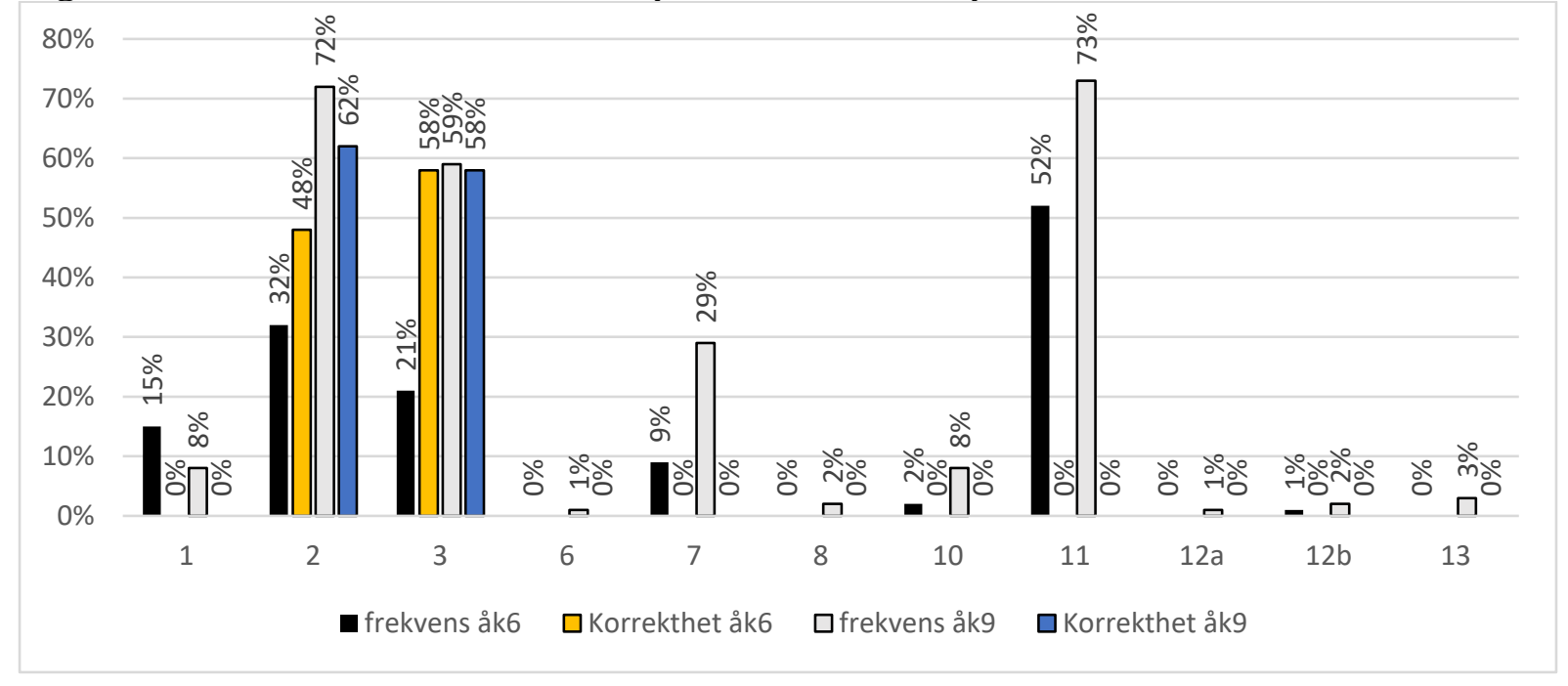

Vara-passiven är i båda årskurserna den vanligaste passivkonstruktionen i mening 11 (ex. 12, $52 \%$ resp. $73 \%$ ). Konstruktionen är dock osannolik i presens i L1-svenska eftersom själva grundandet är avslutat, och även i preteritum (var grundat) eftersom staden fortfarande finns kvar. Att så många informanter ändå använder vara-passiv torde bero på engelsk påverkan (jfr Tampere was founded by Gustav III). Det gäller alltså "en falsk vän" på formnivå (jfr Kantola, 2001; Järvinen [Nyqvist], 2004).

\section{Tampere on Kustaa III:n perustama. (mening 11) Tammerfors vara.3SG.PRS Gustav III-GEN grundad-AGENT Tammerfors grundades/blev grundat av Gustav III.}

Vara-passiven är i åk9 relativt vanlig även i mening 7 (ex. 13), där den ändrar betydelsen, eftersom fokuset då flyttas från förändringen till resultatet. Även här torde det handla om engelsk påverkan (jfr He was dismissed). 


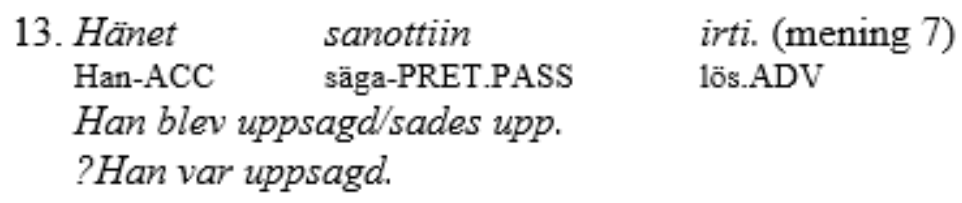

I meningarna 2 och 11 förekommer även icke-normenliga agentadverbial i form av en $s$-genitiv: "Den här dikt är *Runebergs skrivet", "Tammerfors är Gustav *IIIs grundad". De torde ha sina rötter i de finska motsvarigheterna, där egennamnen innehåller en genitivändelse ( $n$; t.ex. Kustaa III:n perustama, "grundat av Gustav III", ett s.k. agentparticip (ISK, 2004, s. 515)). Detta icke-normenliga agentadverbial förekommer i dessa två meningar nästan enbart när inläraren valt vara-passiv och adverbialen är signifikant vanligare i åk6 än i åk9 (p<0,001).

På grund av de talrika allomorferna och kongruensböjningen är particip problematiska för inlärare (se även Kantola, 2001; Järvinen [Nyqvist], 2004, s. 85). Utebliven genuskongruens är det vanligaste problemet, men meningarna 2 och 7 med starkt resp. oregelbundet verb visar även andra typer av avvikelser: i mening 2 överanvänds supinum (skrivit) i åk6, medan det i åk9 förekommer även andra normavvikelser t.ex. *skrivad; *skrevt. I mening 7 överanvänds neutrum/supinumformen (sagt), men några bildar också particip enligt första konjugationen: Han blev *uppsägat. I åk9 ser vi signifikant fler avvikelser i form av överanvänd neutrum/supinumform än participformer som böjts enligt fel konjugation $(\mathrm{p}<0,001)$ så konjugationen verkar de då ha lärt sig.

I meningar med regelbundna verb handlar problemen framför allt om kongruensen. I meningar med subjekt i singular handlar det oftast om genuskongruens: t.ex. överanvänds formen beundrat (identisk med supinumformen) i mening $3 \mathrm{i}$ båda årskurserna signifikant mer än pluralformen (beundrade; $\mathrm{p}=0,012$ i åk6; $\mathrm{p}<0,001$ i åk9). I mening 11 överanvänds utrumformen (grundad) signifikant mer än pluralformen (Tammerfors var *grundade, p<0,001). I mening 13 är utebliven kongruensböjning (Huset kan bli *byggd) signifikant vanligare än particip som böjts enligt första konjugationen $(\mathrm{p}=0,039, *$ byggad $)$. I meningarna 1 och 10 förekommer däremot utebliven pluralkongruens: Fönstren blir *stängd, men även particip som böjts enligt den första konjugationen, Priserna blev *höjad.

Gemensamt för både vara- och bli-passiv är alltså att normavvikelserna är kopplade till själva verbformerna. Perfekt participformerna är svåra att bilda, men också att böja framför allt enligt genus. Det förekommer också viss överanvändning av vara-passiven, troligen pga. engelsk påverkan. Dessutom finns det några belägg på en icke-normenlig agentkonstruktion som troligen beror på finsk påverkan och som är sällsyntare i åk9.

\subsection{Blandformer}

Blandformen man $+s$-form (t.ex. Man *sägs att...) är vanligast i åk6 (21 av de sammanlagt 25 beläggen i åk6, 36 av de 75 beläggen i åk9), medan vara/bli $+s$-form (t.ex. Priserna blev *höjas) dominerar i åk9 (4 belägg i åk6, 38 i åk9). Man $+s$-form förekommer i kontexter där båda konstruktionerna vore acceptabla, medan vara/bli $+s$-form förekommer där perifrastisk passiv inte är sannolik bland L1-skribenter. Blandformer är signifikant $(\mathrm{p}<0,001)$ vanligare $\mathrm{i}$ åk9 där vara-passiv är frekventare.

\section{Sammanfattande diskussion}

Vår analys visar att skillnaderna mellan de två årskurserna är små och $s$-passiven är vanligast av de egentliga passivkonstruktionerna i båda grupperna. Egentlig passiv blir vanligare i åk9, medan åk6 använder aktiva konstruktioner mer. Vad gäller egentlig passiv dominerar $s$ - 
passiven i båda årskurserna. Bli-passiven är sällsynt i båda grupperna, medan vara-passiven är vanligare och t.o.m. verkar överanvändas en del. Fördelningen mellan de olika passiverna stämmer bra överens med tidigare forskning om L1-svenska där $s$-passiven klart dominerat och således bör vara den passiv som förekommer mest i inputen vilket också gör den enklare att lära sig. Dessutom är $s$-passiven formellt enklare än den perifrastiska som kräver koll på både konjugationer och kongruensböjning vilket förutom dess inputfrekvens sannolikt bidrar till att den behärskas signifikant sämre.

Informanternas problem med passiven handlar om både de formella aspekterna och valet av den idiomatiska konstruktionen. Eftersom testet enbart innehåller verb som kan användas i passiv, förekommer $s$-passiven inte i kontexter där den inte är möjlig. De fătaliga normavvikelserna i $s$-passiv gäller subjektet och tillfogandet av $s$-ändelsen i presens (jfr Kantola, 2001), vilket var väntat både med tanke på tidigare forskning och svårigheten i hur formen bildas.

Bli-passiv överanvänds sällan, medan vara-passiv överanvänds, antagligen pga. dess formella likhet med engelskans passiv (jfr Järvinen [Nyqvist], 2004) men perifrastisk passiv kan anses vara en marginell företeelse överlag. Trots allt kan vi dock notera att informanterna producerar belägg på speciellt vara-passiv (mestadels) i idiomatiska kontexter. Problemen gäller speciellt participformerna och handlar både om bildandet och böjningen. Troligen finns problemen även i övriga kontexter med perfekt particip, detta vore bra att undersöka vidare. De olika analyssätten tillåter inte en direkt jämförelse av de kvantitativa analyserna mellan den aktuella studien och Järvinen [Nyqvist] (2004), men det kan konstateras att normavvikelserna i båda materialen är kvalitativt likartade.

Åk9 använder egentlig passiv i en större utsträckning, och deras $s$ - och vara-passiver är signifikant mer normenliga än i åk6. Intressant är dock att även blandformerna är vanligare i åk9, pga att vara-passiv är vanligare i åk9. De perifrastiska passivformerna introduceras vanligtvis senare än s-passiven i undervisning i svenska som andraspråk. Blandformerna kan således delvis bero på förvirring av att de perifrastiska passivformerna är sällsynta och således kanske först nu funnits nog mycket $\mathrm{i}$ input för att börja kunna läras in. De flesta passiver man stöter på har $s$-form och det kan göra att man tänker att passiv alltid ska ha det även när man försöker tillämpa en perifrastisk form man just lärt sig.

Den svenska passiven är en komplex och understuderad konstruktion ur ett L2-perspektiv framförallt. Vi ser också en tydlig ökning i försöken att använda den egentliga passiven från åk6 till åk9 och överlag är det bland de egentliga passiverna $s$-passiven som visar sig mest frekvent. Detta antar vi stämmer överens med det som inlärarna mest stöter på i input på basis av tidigare studier om passivens fördelning.

Passiven ger problem såväl formellt som i valet av passivkonstruktion, men det är svårt att bedöma vilka former som kan ses som idiomatiska i ett översättningstest med meningar utan klargörande kontext. Det här gjorde det ibland svårt för L1-talare i vår studie att säga vilka passivkonstruktioner som var idiomatiska. Ändå konstaterade vi att eftersom passiver inte är så vanliga i fritt skrivande så finns det fördelar med ett översättningstest. Men vi skulle föreslå att framtida studier försöker hitta sätt att undersöka valet mellan de olika passivkonstruktionerna genom t.ex. luckor i lite längre textsekvenser och/eller bedömning av idiomaticitet i färdiga satser med olika passivkonstruktioner. 
Vi ser tecken på problem med argumentens realisering i de passiva satserna sannolikt pga L1, där det aktiva objektets kasusform lämnats kvar i passiven. Med tanke på detta och de övriga skillnader som vi beskrivit mellan passiv i svenska och finska anser vi att en studie kring passiv och tolkningen av argumentens semantiska roller kunde vara givande att göra för finska och svenska utifrån competition model. Tidigare studier har visat att ledtrådar kan vara olika starka i olika språk, således kan t.ex. ordföljd vara starkare ledtråd till semantiska roller i ett språk och morfologi i ett annat och detta kan ha ett inflytande på L2-bruket (jfr Liu m.fl., 1992). Vi ser tecken i vårt material på att detta kan vara något som orsakar problem för inlärarna som ibland väljer att sätta subjektet i de passiva satserna i oblik form: *Henne sågs igår... De typologiska skillnaderna mellan svenska och finska gör det sannolikt att många ledtrådar skulle ha olika värden i språken. Dock är det inget som måste påverka L2-inlärningen av det andra språket eftersom Liu m.fl. (1992) visat att om man lär sig L2 tidigt utnyttjar man inte nödvändigtvis L1:s ledtrådsvärden i sin tolkning av L2. Detta betyder att för något som skiljer sig åt så pass mycket mellan språken som passiv kan den tidiga startåldern ge språkbadselever en klar fördel i inlärningen. Det här vore intressant att studera vidare också genom jämförande studier mellan språkbadselever och elever i traditionell undervisning. Exempelvis kunde det också vara intressant att ge lucktest där formen för subjektet i den passiva meningen ska anges som ett pronomen vilket således tydligt visar om det är objekt eller subjekt. Helst skulle man vilja testa både hur inlärarna analyserar de semantiska rollerna hos argumenten i satsen och hur de väljer att markera den syntaktiska funktionen på argumenten i den passiva satsen.

Det vore även intressant att undersöka hur passiven ser ut hos mycket avancerade inlärare, t.ex. studerande eller doktorander i nordiska språk eller svenska språket med svenska som L2. Eftersom språkbad i Finland bara sträcker sig upp till åk9 så kan äldre informanter i likadana skolkontexter inte hittas, men det skulle också vara viktigt att med hjälp av bakgrundsinformation kunna urskilja de inlärare som gått i språkbad under sin grundskola i studier av äldre inlärare på gymnasie- och universitetsnivå för att se vilken skillnad detta kan ge i längden. Om inlärare fortsätter att få tillräckligt med input är det möjligt att den perifrastiska passiven blir mer normenlig. Behärskningen av perfekt particip borde också kontrolleras i icke-passiva kontexter och dess utveckling i relation till input kontrolleras både för perifrastisk passiv och i övriga kontexter.

Att behärska grammatikregler är inget självändamål för språkinlärning. Genesees (2004) definition för funktionell tvåspråkighet som språkbadets ändamål antyder dock att grammatisk korrekthet trots allt är en central del av språkkunskaperna. Grammatisk korrekthet kan vara något som förväntas för att korrektheten i texter påverkar läsarens inställning till dem och för att det också kan påverka tolkningen om det finns normavvikelser. Exempelvis kan oblik form på subjektet orsaka förvirring hos läsaren. Därför finns det skäl att fundera på olika sätt att hjälpa alla inlärare mot en mer målspråksenlig användning av passiven. I språkbad är det vanligt att behandla grammatik på språklektionerna, medan t.ex. historielektionerna enbart handlar om lärostoffet i historia (Lyster, 2007, s. 126; Morton, 2016). Historialektionen skulle dock kunna erbjuda en bra möjlighet att också fokusera en del på bruket av passiv. Genom samarbete mellan lärarna skulle man kunna lyfta fram passivformerna i läromedlen (jfr noticing, Schmidt, 1990). Likaledes kunde man också inom samhällsvetenskapen väva in viss framhävning av passivformer i nyhetsartiklar med tanke på att passiven visats vara mest vanlig i just nyheter och formellare genrer (jfr Laanemets, 2012). Innehållsinriktad undervisning kan erbjuda möjligheter till att arbeta med språket och grammatiken, eftersom stoffet alltid uttrycks med språkliga medel (jfr Handscombe, 1990, s. 185). Undervisning som leder inläraren till att flytta sin uppmärksamhet mellan "dagens tema" i t.ex. historia och det språk som temat behandlas på möjliggör en destabilisering av normavvikelser i inlärarspråket och lämnar bestående spår i 
minnet (Lyster, 2007). Det vore mycket intressant att titta vidare på effekterna av ett sådant undervisningskomplement på inlärningen av just passiv i framtida studier. Det är dock klart att i synnerhet lärare som undervisar språkbadselever utan att själva ha språkvetenskaplig utbildning behöver stöd och utbildning för att kunna stödja språkinlärningen inom den innehållsriktade undervisningen på ett optimalt sätt. Till viss del kan detta dock göras genom att lärare samarbetar så att svensklärare känner till vad man arbetar med i läsämnena och vilka texter man läser. På så vis kan de eventuellt också kunna påpeka vad andra lärare bör lyfta fram rent språkligt och de kan välja att inkorporera arbete med liknande (eller samma) texter inom svenskan. 


\section{Litteratur}

Abraham, W. (2006). Introduction: Passivization and typology. Form vs. function - a confined survey into the research status quo. I W. Abraham \& L. Leisiö (Red.), Passivization and typology (s. 1-27). John Benjamins.

Bates, E. \& MacWhinney, B. (1989). Functionalism and the competition model. I B. MacWhinney \& E. Bates (red.) The Crosslinguistic study of sentence processing. (s. 3-76). New York: CUP.

Bergroth, M. (2007). Kielikylpyperheet valokeilassa. Taustat ja odotukset. Vaasan yliopiston julkaisuja, Selvityksiä ja raportteja 145. Vasa: Vasa universitet.

Bergroth, M. (2015). Kotimaisten kielten kielikylpy. Vaasan yliopiston julkaisuja. Selvityksiä ja raportteja 202. Vasa: Vasa universitet.

Bergroth, M. \& Björklund, S. (2013). Kielikylpyohjelman tutkimustuloksia Suomessa. I L. Tainio \& H. Harju-Luukkainen (Red.), Kaksikielinen koulu - tulevaisuuden monikielinen Suomi/Tvåspråkig skola - ett flerspråkigt Finland $i$ framtiden (s. 91-114). Suomen kasvatustieteellinen seura. Kasvatusalan tutkimuksia 62.

Bybee, Joan, 2008: Usage-based grammar and second language acquisition. I P. Robinson \& N.C. Ellis (Red.), Handbook of Cognitive Linguistics and Second Language Acquisition (s. 216-236). New York: Routledge.

DeKeyser, R. (2005). What Makes Learning Second Language Grammar Difficult? A Review of Issues. Language Learning, 55, 1-25. DOI: https://doi.org/10.1111/j.00238333.2005.00294.x

Ellis, N. C. (2011 [2013]). Frequency-based accounts of second language acquisition. I S. Gass \& A. Mackey (Red.), The Routledge Handbook of Second Language Acquisition (s. 193-210). Abingdon: Routledge. Routledge Handbooks Online. (Hämtad: 15 aug 2019)

Ellis, N.C. (2016). Salience, Cognition, Language Complexity, and Complex Adaptive Systems. Studies in Second Language Acquisition, 38, 341-351. DOI:https://doi.org/10.1017/s027226311600005x

Ellis, R. (2008). The Study of Second Language Acquisition. 2nd edition. Oxford: OUP.

Ellis, R. \& Barkhuizen, G. (2005). Analysing Learner Language. Oxford: Oxford University Press.

Engdahl, E. (2006). Semantic and syntactic patterns in Swedish passives. I B. Lyngfelt \& T. Solstad (Red). Demoting the agent: Passive, Middle and Other Voice Phenomena (s. 21-45). Amsterdam: Benjamins.

Finlands officiella statistik (FOS): Befolkningsstruktur. Årsöversikt 2019. Helsingfors:

Statistikcentralen http://www.stat.fi/til/vaerak/2019/01/vaerak_2019_01_2020-10-

23_kuv_001_sv.html (Hämtad: 14.12.2020).

Genesee, F. (2004). What do We Know about Bilingual Education for Majority Language

Students? I T.K. Bhatia \& W.C. Ritchie (Red.): Handbook of Bilingualism (s. 547-576).

Malden, MA: Blackwell.

Handscombe, J. (1990). The complementary roles of researchers and practitioners in second language education. I B. Harley, P. Allen, J. Cummins \& M. Swain (Red.), The development of second language proficiency (s. 181-186). Cambridge: CUP.

Hakulinen, A. \& Karlsson, F. (1979). Nykysuomen lauseoppia. Helsingfors: Finska litteratursällskapet.

Harley, B. (1993). Instructional strategies and SLA in early French immersion. Studies in Second Language Acquisition, 15, 245-260. DOI:https://doi.org/10.1017/s0272263100011980 Harley, B. (1998). The Role of Focus-on-Form Tasks in Promoting Child L2 Acquisition. I C. Doughty \& J. Williams (Red.), Focus on form in classroom second language acquisition (s. 156-174). Cambridge: CUP. 
Horbowicz. P., Skrzypek, D., Sobkowiak, M. \& Kolaczek, N. (2019). The use of passive voice in academic writing. Evidence from Danish, Norwegian and Swedish as L1 and L2. Folia Scandinavica Posnaniensia, 26, 4-26. DOI:https://doi.org/10.2478/fsp-2019-0001

Holmes, P. \& Hinchcliffe, I. (1994). Swedish: A Comprehensive Grammar. London: Routledge. Håkansson, C., Lyngfelt, B. \& Brasch, M. (2019). Typfall och mönsterigenkänning konstruktionsbaserad andraspråksundervisning i praktiken. I M. Bianchi, D. Håkansson, B. Melander \& L. Pfister (Red.) Svenskans beskrivning 36 (s. 107-117). Uppsala: Uppsala universitet.

Inkinen-Järvi, M. \& Jokinen, J. (2016). Språkcentrumlärarnas uppfattningar om grammatikens roll på kurserna i L2-svenska vid finländska universitet. I T. Lehtonen \& J. Vaattovaara (Red.) Näkökulmia kielenoppimisen ohjaukseen/On advising and counselling in language learning (157-176). Language Centre publications 6. Helsingfors: Helsingfors universitet.

ISK=Hakulinen, A, Vilkuna, M, Korhonen, R, Koivisto, V, Heinonen, T.R. och Alho, I. (2004). Iso Suomen Kielioppi. Helsingfors: Finska litteratursällskapet.

Juurakko, T. (1996). Prepositioner i finskspråkiga gymnasisters inlärarsvenska. Jyväskylä: Jyväskylä universitet.

Järvinen, E-L. (2004). Passiv diates samt man-konstruktion i finskspråkiga gymnasisters skriftliga inlärarsvenska. Opublicerad avhandling pro gradu. Åbo: Åbo Universitet.

Kantola, K. (2001). Passiven och man-konstruktionen i ett urval abiturientuppsatser från våren 1997. Opublicerad pro gradu-avhandling. Åbo: Åbo universitet.

Karlsson, F. (2009). Finsk grammatik. 9:e uppl. Helsingfors: Finska Litteratursällskapet.

Laanemets, A. (2012). Passiv i moderne dansk, norsk og svensk. Et korpusbaseret studie af tale- og skriftsprog. Tartu: University of Tartu Press.

Laanemets, A. (2013). The passive voice in spoken and written Danish, Norwegian and Swedish - A comparative corpus-based study. Languages in Contrast, 13, 67-89. DOI:https://doi.org/10.1075/lic.13.1.04laa

Laurén, C. (2006). Tidig Inlärning av flera språk. Teori och praktik. Vasa: Vasa universitet. Li, P. \& MacWhinney, B. (2013), Competition model. I C. A. Chapelle (Red.) The Encyclopedia of Applied Linguistics. Blackwell. DOI:https://doi.org/ 10.1002/9781405198431.wbeal0168

Liu, H., Bates, E., \& Li, P. (1992). Sentence interpretation in bilingual speakers of English and Chinese. Applied Psycholinguistics, 13, 451-484.

LoCoco, V. (1976). A Comparison of Three Methods for the Collection of L2 Data: Free Composition, Translation, and Picture Description (s. 59-86). Working Papers on Bilingualism 8.

Lyngfelt, B. \& Prentice, J. (2020). Ett bruksbaserat perspektiv på språkinlärning. Utkast 202003-09.

https://www.academia.edu/42177359/Ett_bruksbaserat_perspektiv_p\%C3\%A5_spr\%C3\%A5 kinl\%C3\%A4rning

Lyster, R. (2007). Learning and Teaching Languages Through Content. A counter-balanced approach. Amsterdam/Philadelphia: John Benjamins.

Löflund, J. (1998). Suomen kirjoitetun yleiskielen passiivi. Åbo: Åbo Akademis förlag.

Martola, N. (2014). Är man passivare på finlandssvenska? En kontrastiv undersökning av tidningsspråk. I R. Kosunen, K. Lepistö, P. Rossi (Red.), Svenskan i Finland 14 (s. 151-158). Uleåborg: Uleåborgs universitet.

Morton, T. (2016). Conceptualizing and investigating teachers' knowledge for integrating content and language in content-based instruction. Journal of Immersion and Content-based Language Education, 4, 144-167. DOI:https://doi.org/10.1075/jicb.4.2.01mor

Neuvonen, T. (1997). Valet mellan de olika passiva konstruktionerna i svenskan med speciell hänsyn till bruket i studentuppsatser. Joensuu: Joensuu universitet. 
Nyqvist, E-L. (2018a). Definiteness and Use of Articles in Written Swedish by Finnishspeaking Immersion Pupils at the End of Immersion: a Comparison with Non-immersion Students. Journal of Immersion and Content-based Language Education 6, 57-84. DOI:https://doi.org/10.1075/jicb.17001.nyq

Nyqvist, E-L. (2018b). Species och artikelbruk hos finska språkbadselever i årskurs 6 . Folkmålsstudier 56, 73-104. https://journal.fi/folkmalsstudier/article/view/89161

Nyqvist, E-L. (2018c). Mastering complex Swedish NPs: A comparison of non-immersion pupils and immersion L1 Finnish pupils. Journal of European Second Language Association, 14-23. DOI:https://doi.org/10.22599/jesla.33

Nyqvist, E-L. (2020). Interrogativa bisatser hos 12- och 15-åriga språkbadselever. En jämförelse med traditionell undervisning. I C. Wide, E. Ingman, K. Lankinen \& V. Vaakanainen (Red.) Svenskan $i$ Finland 18 (s. 164-180). Åbo: Åbo universitet. https://www.utupub.fi/bitstream/handle/10024/150838/Wide_mfl_2020_Svenskan_i_Finland. pdf

Nyqvist, E-L. \& Lundkvist, P. (2020). De lokala prepositionerna hos finska svenskinlärare i språkbad och traditionell undervisning. I S. Haapamäki, L. Forsman \& L. Huldén (Red.) Svenskans beskrivning 37 (s. 215-229). Åbo: Åbo Akademi.

Ó Duibhir, P. (2009). The Spoken Irish of Sixth-class Pupils in Irish Immersion Schools. Dublin: University of Dublin, Trinity College, Centre for Language and Communication studies.

Pawley, A. \& Syder, F. (1983). Two puzzles for linguistic theory: nativelike selection and nativelike fluency. https://lextutor.ca/rt/pawley_syder_83.pdf (Senast hämtad: 12 juli 2019)

Prentice, J., Loenheim, L., Lyngfelt, B., Olofsson, J. \& Tingsell, S. (2016). Bortom ordklasser och satsdelar: Konstruktionsgrammatik i klassrummet. I A. W. Gustafsson, L. Holm, K. Lundin, H. Rahm \& M. Tronnier (Red.) Svenskans beskrivning 34 (s. 385-397). Lund: Lunds universitet.

SAG = Teleman, U, Hellberg, S. \& Andersson, E. (1999). Svenska Akademiens Grammatik 14. Stockholm: Norstedts Ordbok.

Schmidt, R.W. (1990). The role of consciousness in second language learning. Applied Linguistics, 11, 129-158. DOI: https://doi.org/10.1093/applin/11.2.129

Seliger, H. (1989). Semantic Transfer Constraints on the Production of English Passive by Hebrew-English Bilinguals. I H. Dechert \& M. Raupach (Red.), Transfer in Language Production (s. 21-34). New Jersey: Ablex Publishing.

Siewierska, A. (1984). The passive - A Comparative Linguistic Analysis. London/Sydney / Dover: Croom Helm.

Sipola, S. (2008). Den språkliga korrektheten i uppsatser på svenska. I T. Swanström (Red.) Språkbad: två språk i utveckling. Kielikylpy: kaksi kieltä kehityksessä (s. 79-91). Åbo: Skrifter från Svenska institutionen vid Åbo Akademi.

Skehan, P. (1998). A cognitive approach to language learning. Oxford: OUP.

Utbildningsstyrelsen, (2014). Grunderna för den grundläggande utbildningen. Helsingfors: Utbildningsstyrelsen. https://www.oph.fi/sv/utbildning-och-examina/grunderna-laroplanenden-grundlaggande-utbildningen (Hämtad: 19 aug. 2019)

Warren, B. (2005). A model of idiomaticity. Nordic Journal of English Studies, 4 (1): 35-54. http://130.241.16.45/ojs/index.php/njes/article/viewFile/270/267 (Hämtad: 29 nov. 2020) 
Finnish immersion pupils' use of Swedish passive

\section{Abstract}

The Swedish passive has a variety of forms (s-passive, vara- and bli-passive). It also differs from the other Scandinavian languages in the dominance of the s-passive. In this article we analyse L2 Swedish translations of Finnish sentences to see how well a group of immersion learners can form passives and which passive construction they prefer. We compare immersion students in year 6 and 9 to see if there is any improvement and also if there is a difference in what they tend to have problems with or in the constructions they prefer to use.

Our results show that the $s$-passive is the most common in both years (as in L1 Swedish) and that the periphrastic forms increase in year 9 but that their form still causes problems. Year 9 reaches a higher level of formal correctness in $s$ - and vara- passives, however since they use more complex forms more often this sometimes leads to inaccuracies. Our results show problems primarily in relation to the form and not in the choice of the passive construction, although construction choice is difficult to judge out of a bigger context and this would be worth looking at more in the future.

Keywords: Swedish as a L2, Swedish grammar, complexity, immersion, passive 
Bilaga 1: De finska meningarna i testet och de acceptabla svenska översättningarna

\begin{tabular}{|c|c|c|}
\hline nr. & Mening på finska & Acceptabla svenska översättningar \\
\hline 1 & Huolehdi, että ikkunat suljetaan! & $\begin{array}{l}\text { Se till att fönstren stängs! } \\
\text { Se till att fönstren är stängda! } \\
\text { ?Stäng fönstren. }\end{array}$ \\
\hline 2 & Tämä runo on Runebergin kirjoittama. & $\begin{array}{l}\text { Den här dikten är skriven av Runeberg. } \\
\text { Den här dikten skrevs av Runeberg. } \\
\text { (Runeberg skrev den här dikten. } \\
\text { ?Den här dikten har skrivits av Runeberg.) }\end{array}$ \\
\hline 3 & Häntä ihailtiin 80-luvulla. & $\begin{array}{l}\text { ?Han/hon beundrades på 80-talet. } \\
\text { ?Han/hon var beundrad på 80-talet. }\end{array}$ \\
\hline 4 & Ystävistään täytyy pitää huolta. & Man ska ta hand om sina vänner. \\
\hline 5 & Se on kiellettyä. & Det är förbjudet. \\
\hline 6 & Paita pitää pestä 40 asteessa. & Skjortan ska tvättas i 40 grader. \\
\hline 7 & Hänet sanottiin irti. & $\begin{array}{l}\text { Han/hon blev uppsagd. } \\
\text { Han/hon sades upp. } \\
\text { Han/hon fick sparken. }\end{array}$ \\
\hline 8 & $\begin{array}{l}\text { Sanotaan, että koira on ihmisen paras } \\
\text { ystävä. }\end{array}$ & Det sägs att hunden är människans bästa vän. \\
\hline 9 & Kun on sairas, täytyy levätä. & $\begin{array}{l}\text { När man är sjuk måste man vila. } \\
\text { När du är sjuk måste du vila. }\end{array}$ \\
\hline 10 & Hintoja korotettiin. & $\begin{array}{l}\text { Priserna höjdes. } \\
\text { ?Priserna blev höjda. }\end{array}$ \\
\hline 11 & Tampere on Kustaa III:n perustama. & $\begin{array}{l}\text { Tammerfors grundades av Gustav III. } \\
\text { ?Tammerfors blev grundat av Gustav III. } \\
\text { (Gustav III grundade Tammerfors.) } \\
\text { ?Tammerfors är/var grundat av Gustav III. }\end{array}$ \\
\hline $12 \mathrm{a}$ & Kerrotaan, & Det berättas/sägs/talas om \\
\hline $12 \mathrm{~b}$ & että Turun seudulla on nähty karhuja. & $\begin{array}{l}\text { att björnar sågs } i \text { Åbotrakten... } \\
\text { att björnar har blivit sedda i Äbotrakten. } \\
\text { att björnar har setts } \text { i Åbotrakten. } \\
\text { att björnar har synts i Åbotrakten. } \\
\text { att man har sett björnar i Åbotrakten. }\end{array}$ \\
\hline 13 & Talo voidaan rakentaa ensi vuonna. & $\begin{array}{l}\text { Huset kan byggas nästa år. } \\
\text { Huset kan bli byggt nästa år. }\end{array}$ \\
\hline
\end{tabular}


i Tack till Turku Institute of Advanced Studies och till Riksbankens Jubileumsfond (P17-0716:1) för finansiering under tiden för studien. Tack till våra kollegor för kommentarer i koppling till presentationer av studien.

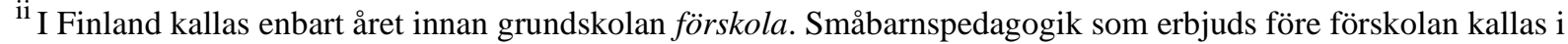
Finland daghem eller dagvård. Språkbadet börjar ofta i 4-5 års ålder (Bergroth, 2007, s. 18).

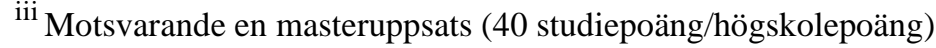

${ }^{\text {iv }}$ Studerande i den sista årskursen i det finska gymnasiet.

v Samma test har använts i materialinsamlingen för den aktuella undersökningen.

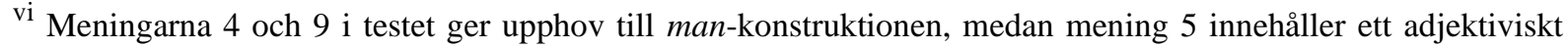
particip. Dessa lämnas utanför denna studie. Mening 12 innehåller två kontexter där en passivkonstruktion är möjlig.

vii Jfr analys av obligatoriska kontexter som utgår från de former som informanten borde använda enligt målspråksnormen (R. Ellis \& Barkhuizen, 2005, s. 73). 